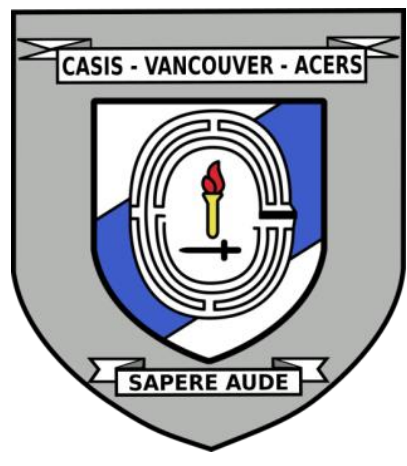

\title{
OPERATIONALIZING HUMAN SECURITY IN THE CONTEMPORARY OPERATING ENVIRONMENT
}

Date: November 24, 2021

Disclaimer: This briefing note contains the encapsulation of views presented by the speaker and does not exclusively represent the views of the Canadian Association for Security and Intelligence Studies.

\section{KEY EVENTS}

On November 24, 2021, Mr. Stephen Anning presented on Operationalizing Human Security in Contemporary Operating Environment at the 2021 CASIS West Coast Security Conference. The key points of discussion included the concept of human security, the differences between interstate and intrastate conflict, the challenges of understanding human security, and how operationalizing human security can address some of those challenges. The presentation was followed by a question and answer period with questions from the audience and CASIS Vancouver executives.

\section{NATURE OF DISCUSSION}

\section{Presentation}

Mr. Anning's presentation focused primarily on how human security fits within the contemporary operating environment and how population intelligence can operationalize human security. Mr. Anning also discussed the challenges of operationalizing human security and the role of data analytics in operationalizing human security.

\section{Question Period}

During the question and answer period, Mr. Anning discussed the dangers of using the term 'terrorism' too broadly, as well as the importance of offline community engagement when countering radicalization since sole online interventions can sometimes do more harm than good. 


\section{BACKGROUND}

\section{Presentation}

Mr. Anning began his presentation by pointing out that using data driven approaches allow the operationalization of human security in the contemporary operating environments when researching security issues. Mr. Anning then proposed Population Intelligence (POPINT) as a way to operationalize human security. The concept of human security was first developed in the 1990s in humanitarian communities and has been reinvigorated in recent years in military organizations. It has been used to explore the utility of operation effectiveness regarding the need to better understand the complexity of the operating environments and a population in particular.

Mr. Anning argued that human security is a response to many of the population's problems in contemporary operating environments. Furthermore, research has provided a better understanding of the drivers of conflict and insecurity in a population. Population is the interplay between state security and human security, and although the objectives between state security and human security are different, the contrast is, arguably, not a trade-off but complementary to each other.

In 1994, the idea of human security was first proposed in a report by the United Nations. In 2012, the United Nations General Assembly Resolution defined human security as an approach to assist member states in identifying and addressing widespread and cross-cutting challenges to the survival, livelihood, and dignity of their people. The themes identified included economic, food, health, environmental, personal, community, and political challenges. The idea is that these are the security concerns of a population that would need to be addressed to resolve conflicts.

Data has shown that since World War II to the last decade, interstate conflicts (contests between states) have remained relatively infrequent, whereas intrastate conflicts (contests between state and its people) are comparatively prominent. Further, interstate conflict is about operating within the international system and characterized by industrial machinery of warfare, while intrastate conflict is about operating within the social settlement of a state and characterized by improvised devices and large-scale criminality and human rights abuses. However, since the early 2000s, there has been an increase in internationalized intrastate conflicts, which reflects the interplay between interstate and intrastate conflicts. 
While interstate conflict is enemy centric and intrastate conflict is more human centric, the interplay of the two makes the contemporary operating environments complex, but an analysis of the population can bring a better understanding of the nature of conflicts. With the increased provenance of population, to which human security is arguably the response, the challenges of understanding human security include getting to know the unknown and understanding the importance of the context and thematic domains.

In interstate warfare, for example, the first challenge is finding out what the commanders need to know, which is answered by military intelligence. However, intelligence about population, or the 'ground truth,' is highly subjective. As an example of what 'ground truth' means here, Mr. Anning posited that maps represent a political truth of the people that make that particular state, but not everyone who fits in that map would recognize the 'truth' reflected by the map.

Furthermore, operating within the international system is more likely to be consistent than operating within the social settlement of a state, which is more likely to be unique to the operating environment of that particular state. To appreciate the importance of the context, analysts need to understand what the social assessment is as opposed to understanding international relations.

The final challenge is determining relevant human security themes, such as anticorruption, human-trafficking, and climate change. These themes are all dynamic and interacting with each other and thus it is necessary to understand how each theme fits in a given context and to what extent.

Mr. Anning concluded his presentation by noting that operationalizing human security with data analytics can address some of these challenges. With the advent of new technologies since 1994, data gathered via the intelligence cycle enabled by artificial intelligence processes present new opportunities to produce intelligence on human security. For example, a knowledge graph through artificial intelligence can meaningfully connect different entities in a database, helping to determine what is not known. This is how population intelligence compliments other types of intelligence such as geospatial intelligence or signal intelligence.

\section{Question Period}

In reference to a question about defining terrorism, Mr. Anning noted that applying this word too broadly to any terrorizing act, is giving inappropriate political legitimacy to criminal acts that do not deserve any kind of political legitimacy. Terrorism can often be defined as actions carried out by armed groups 
targeting a population with messages of a political nature. However, he pointed out that defining terrorism can sometimes result in 'concept creep.' For instance, after the Terrorism Act 2006 in the UK, any kind of terrorizing act is considered to be an act of terrorism, consequently, losing the political nature in which a government policy or government change is the target. Mr. Anning added that, according to the original definition, for someone to commit a terrorist act, it needs to be presumed that one day they could be in a position of government.

When asked how effectively he thought the internet could be used to for deradicalization as virtual extremism continues to rise, Mr. Anning stated that virtual or cyber terrorism or extremism do not exist. It is not a dichotomy where we have an online world and an offline world. There is only one world, and the Internet is a huge digital mirror that reflects human thoughts, beliefs, and behaviors. Hence, cyber terrorism or virtual extremism does not exist; there is just terrorism and extremism. Mr. Anning then added that online intervention should be combined with offline community outreach since dehumanization is a crucial part of radicalization. Therefore, a possible counter-radicalization narrative is to humanize the targets/population of hate or conspiracy theories. It is also important to recognize that the disinhibition of online interventions can result in well-meaning actions potentially doing more harm than good.

\section{KEY POINTS OF DISCUSSION}

\section{Presentation}

- Data driven approaches allow the operationalization of human security in the contemporary operating environments when researching security issues.

- Interstate conflict is about operating within the international system and characterized by industrial machinery of warfare.

- Intrastate conflict is about operating within the social settlement of a state and characterized by improvised devices and large-scale criminality and human rights abuses.

- The challenges of understanding human security include getting to know the unknown and understanding the importance of the context and thematic domains.

- Operationalizing human security with data analytics can address some of the human security challenges as artificial intelligence processes present new opportunities to produce intelligence on human security.

The Journal of Intelligence, Conflict, and Warfare Volume 4, Issue 3 


\section{Question Period}

- Applying the word 'terrorism' too broadly to any terrorizing act, is giving inappropriate political legitimacy to criminal acts that do not deserve any kind of political legitimacy.

- Our world is not a dichotomy where we have an online terrorism and an offline terrorism. There is only one world, and the Internet is a huge digital mirror that reflects human thoughts, beliefs, and behaviors.

\section{(@) $\Theta \Theta$}

This work is licensed under a Creative Commons Attribution-NonCommercial-NoDerivatives 4.0 International License.

(1) (STEPHEN ANNING, 2022)

Published by the Journal of Intelligence, Conflict, and Warfare and Simon Fraser University

Available from: https://jicw.org/

The Journal of Intelligence, Conflict, and Warfare Volume 4, Issue 3 